\title{
Detection of Quarry Blasts in the Koyna-Warna Region, Western India
}

\author{
D. Shashidhar, K. Mallika, N. Purnachandra Rao, H. V. S. Satyanarayana, H. K. Gupta \\ CSIR-National Geophysical Research Institute, Hyderabad, India \\ Email: shashi.geo@gmail.com
}

Received 24 September 2014; revised 23 October 2014; accepted 20 November 2014

Copyright @ 2014 by authors and Scientific Research Publishing Inc.

This work is licensed under the Creative Commons Attribution International License (CC BY).

http://creativecommons.org/licenses/by/4.0/

(c) (i) Open Access

\begin{abstract}
Koyna-Warna is a seismically active region, characterized by earthquakes triggered by loading of artificial water reservoirs. In this region quarrying is ongoing and sometimes the quarry blasts are confused with triggered seismic events. About 410 events around a known mining area were observed during January 2007-0ctober 2013. In general the quarry blasts are carried out mostly during the day time. Based on this fact a well known method of [1] is implemented, which has the capability of detecting the areas of quarry blast activity. Also, discrimination of quarry blasts from earthquakes has been achieved by studying waveforms at key seismic stations located close to the quarrying area. Further, distinction is achieved through spectral analysis in the frequency band of 3 - $15 \mathrm{~Hz}$. Ratio of day-time to night-time events, waveform pattern and spectral analysis approach confirm the presence of quarry blasts aligned south-east of the Warna reservoir.
\end{abstract}

\section{Keywords}

Quarry Blasts, Koyna, Reservoir, Seismicity, Warna, Frequency

\section{Introduction}

The Koyna-Warna region situated in the Deccan Volcanic Province of peninsular India is well known for reservoir triggered seismicity [2] [3]. The initiation of seismic activity after the impoundment of the Shivaji Sagar Lake behind the Koyna Dam in 1962 and thereafter, has been investigated by several researchers [3]-[9]. The CSIR-National Geophysical Research Institute (CSIR-NGRI) has been monitoring the seismic activity of the Koyna-Warna region for the past several years. Since August 2005, a closely spaced network with near real time monitoring has been set up. This has enabled identification of a nucleation that precedes moderate earthquakes of magnitude 4.0 to 5.0 [5] [6].

In a previous study a new zone of seismic activity further south-east of the Warna reservoir was reported with

How to cite this paper: Shashidhar, D., Mallika, K., Purnachandra Rao, N., Satyanarayana, H.V.S. and Gupta, H.K. (2014) Detection of Quarry Blasts in the Koyna-Warna Region, Western India. Open Journal of Earthquake Research, 3, $162-169$. 
sparse data from seismic stations available at that time [10]. It was inferred that the seismic activity could be due to pore pressure diffusion probably due to impoundment of a small check dam nearby. During March 2011 more seismic stations were added to the network of which 2 stations started functioning very close to the zone located at south-east of Warna reservoir as shown in Figure 1. From the large number of events recorded, it was felt that this could be associated with quarry mine blasts rather than earthquake activity. Although the problem of discriminating quarry blasts, mining activity, etc. from natural earthquakes is not a trivial one, several studies have been carried out in different parts of the world by several researchers using seismic data to address this issue [11]-[14].

In the present study, a similar approach has been attempted in the seismically active Koyna-Warna region of western India. We examine the catalogue and waveforms of the recorded events to test for the presence of any blasts during the period of January 2007-October 2013. All events investigated lie within the south-east zone marked with a dotted ellipse in Figure 1, hence forth referred as the south-east zone. We adopted the method developed by [1], which identified artificial/mining events. Additionally, waveform data recorded at seismic stations situated close to these events are used for discrimination between earthquakes and artificial events. A multi-pronged approach has been used to analyze the characteristic features like temporal isolation of events, $R_{q}$ values, energy in the surface waves, spectral frequency band and $\mathrm{P}$ wave polarities, to unambiguously discriminate quarry blasts from earthquakes, for the first time in the Koyna-Warna region.

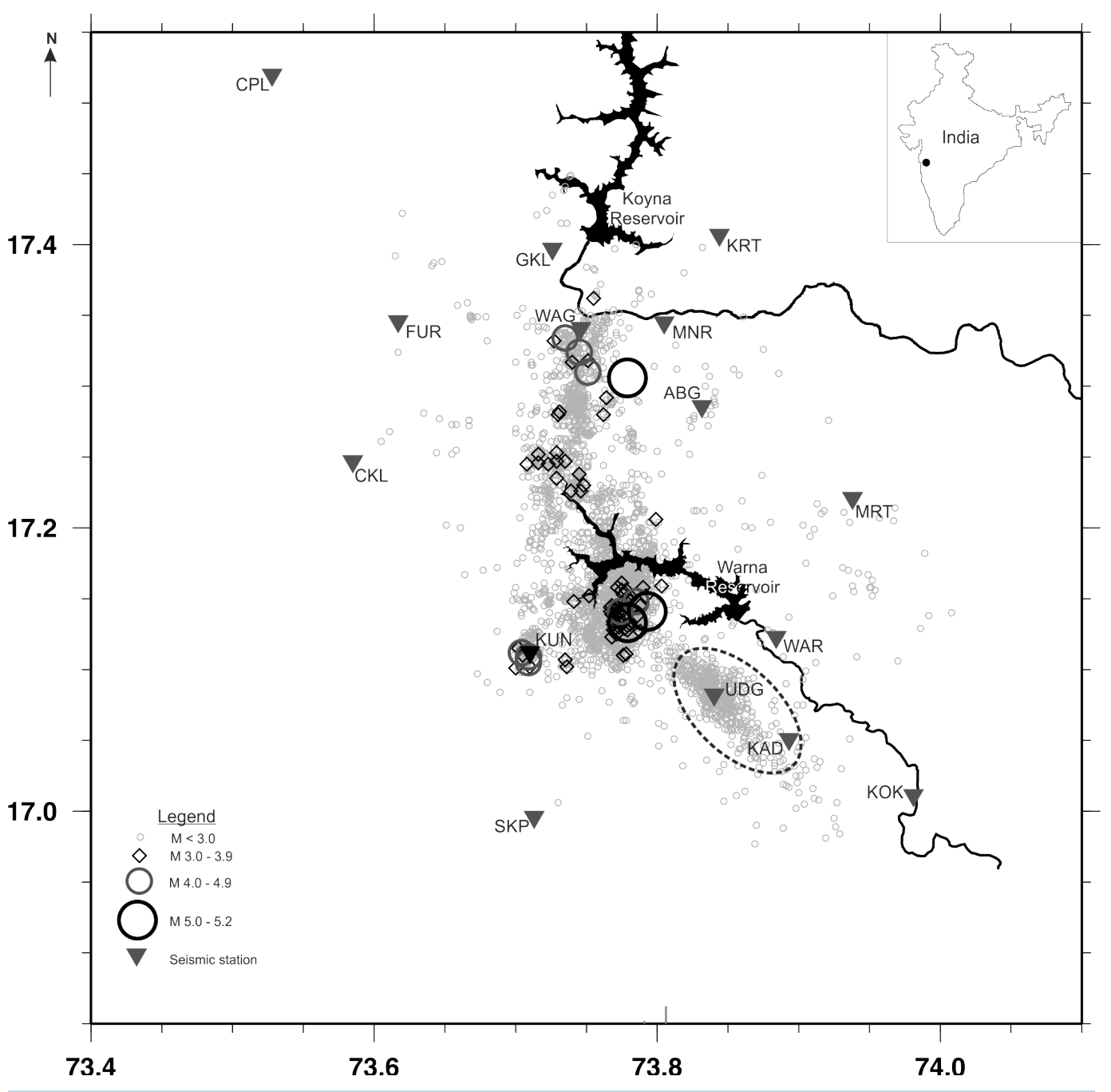

Figure 1. Seismicity of the Koyna-Warna region, western India, from January 2007 to October 2013. The dotted ellipse indicates the events of the south-east zone analyzed in the present study. Inset: Map of India indicating the study region. 


\section{Data and Methodology}

The CSIR-National Geophysical Research Institute, Hyderabad, in India is operating a network of 11 digital seismic stations since 2005 in the Koyna-Warna region. Five of them are broadband (CMG-3-ESP) systems, while the remaining are short-period (L4-3D) seismometers. During January-March 2011 the short period seismometers were replaced by Reftek broad-band sensors (Reftek model 151 - 120) and 2 additional stations were installed strengthening the network to a total of 13 broad-band seismic units (Figure 1). The data are recorded by Reftek data loggers at all the stations, while time synchronization is done through GPS. Typically, locations of earthquakes are good within 500 to $1000 \mathrm{~m}$. Standard earthquake analysis program hypocenter [15] [16] has been used for analysis. The seismicity that occurred during January 2007-October 2013, which is considered in this study, is plotted in Figure 1.

In the present study different approaches have been adopted to differentiate the quarry blasts from earthquakes. At first, seismograms of the events are inspected to bring out peculiarities in the nature of the waveforms. Anomalous temporal variations in the catalogue are investigated to look for clustering of events during day-time in the area of investigation. To assess this, a well established approach developed by [1] is adopted, which is based on the fact that quarry blasts are generally performed during the day-time hours, helping in identification of quarry/mine explosions from earthquakes. In this approach spatial mapping of the ratio of the day-time and night-time events is done for identification of regions with quarry activity which can be defined as areas with a ratio $\left(R_{q}\right) \geq 1.5$. In general the quarry-rich areas show increase in the number of detected events during daytime hours. The parameter $R_{q}$ can be expressed as

$$
R_{q}=\left(N_{d} L_{n}\right) /\left(N_{n} L_{d}\right)
$$

where $N_{d}$ is the total number of events during the day time, $N_{n}$ is that during the night time, $L_{d}$ is the number of hours during the day time and $L_{n}$ is that during the night time $\left(L_{n}+L_{d}=24\right)$. This ratio is calculated using a regularly spaced grid covering the study area and sampling only the $N\left(N=N_{d}+N_{n}\right)$ closest epicenters to each node. The code performs a grid search over the $N$ parameter space $\left(N_{\min }=50, N_{\max }=400, N_{\text {step }}=50\right)$ to identify the sample size with the highest $R_{q}$. Therefore, the parameter space spans three dimensions: latitude, longitude and sample size $N$. This analysis on the catalogue has been carried out using the program ZMAP 6.0 [17] [18]. Further, spectral analysis has been also carried out on selected waveforms of the study region, where amplitudes at various frequencies are examined for comparable magnitude events.

\section{Results and Discussion}

\subsection{Distribution of Events in Time and Space}

The seismicity of the Koyna-Warna region from January 2007 to October 2013 shows a concentration of earthquake clusters, one near Koyna, where the Koyna River takes a sharp bend towards east and another in the vicinity of the Warna reservoir accounting for most of the seismic activity, and finally a small zone south-west of the Warna reservoir (Figure 1) [6] [19]. Previously, [6] reported the association of earthquakes of magnitude exceeding 3 with these seismic clusters. The zone further south-east of the Warna reservoir was also documented based on events detected with a sparse data set [10]. Later this zone has become prominent with about 410 events in the magnitude range 0.8 - 2.8 during the last seven years. The absence of seismic activity during monsoon each year, as also the peculiar nature of waveforms prompted us to examine this zone for possible blasts, as it is located in a known place of quarrying.

The seismicity in the Koyna-Warna region as a function of time seems to be distributed quite uniformly, except for the south-east zone events (dark shaded) which follow a specific time pattern usually during 12 - 18 hours (Indian Standard Time) as seen in Figure 2. This is also shown separately in Figure 3(a). It is also evident that most of these events occurred during weekdays (Figure 3(b)). On a monthly scale (Figure 3(c)) a clear absence of activity is visible in the monsoon months of July to September each year.

The evidence from temporal observations necessitates a detailed spatial analysis of events using the algorithm of [1] as discussed. Figure 4 shows the spatial variation of $R_{q}$, the ratio of day-time and night-time events, in the study region. The marked portion by an ellipse indicates a high $R_{q}$. This map was computed for events with $M \geq$ 1.8, using a sampling size $N=50$ earthquakes and a node spacing of $0.5 \mathrm{~km}$. High $R_{q}$ values more than 1.5 indicate quarry-rich areas. Verification with the location of a known quarry confirms that this area is indeed the 


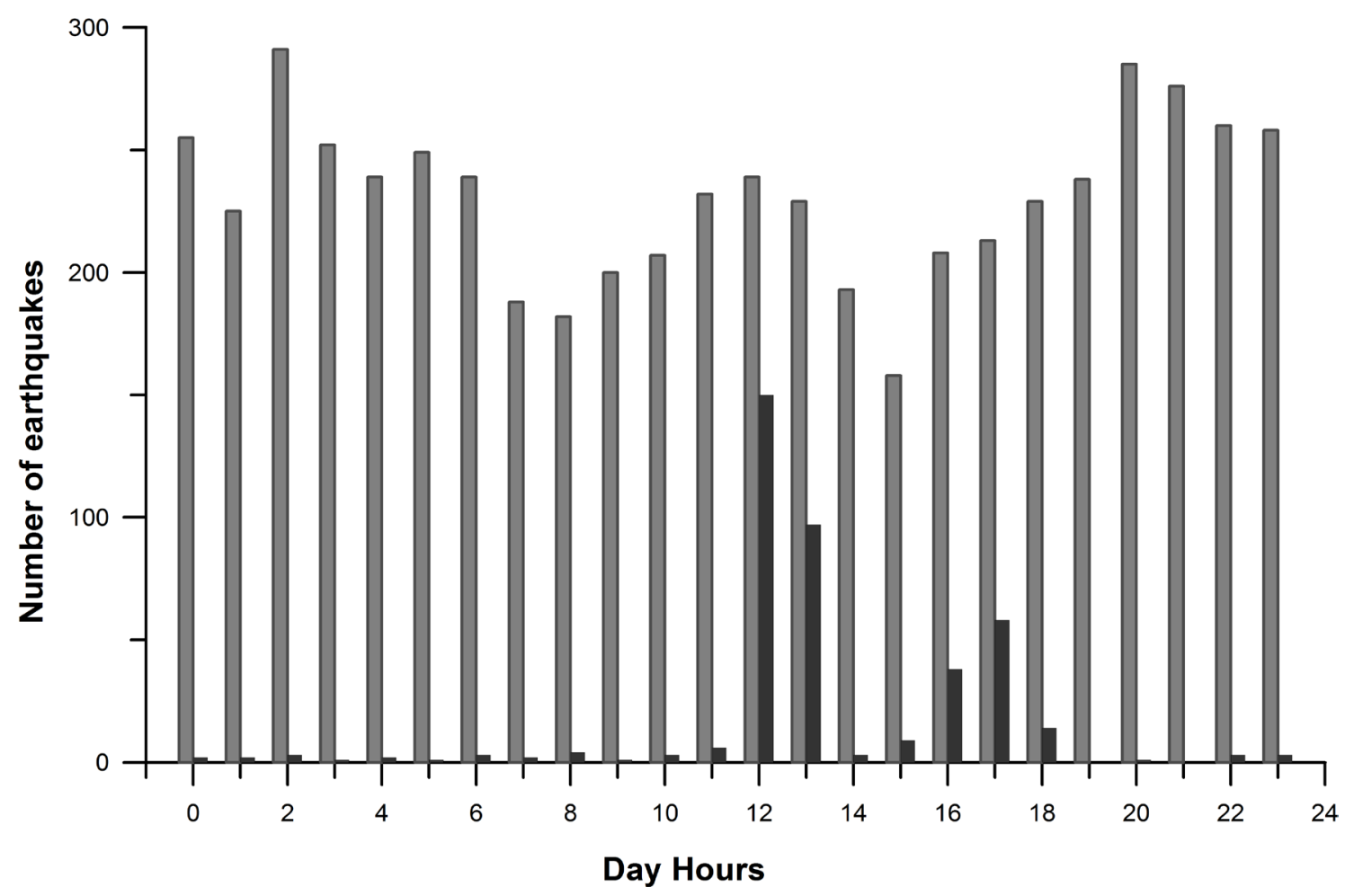

Figure 2. Number of earthquakes of the Koyna-Warna region during January 2007-October 2013 as a function of time. Gray color bars represent events from the entire region whereas the black bars indicate the south-east zone events marked by a dotted ellipse in Figure 1.

location of quarry blasts [20]. The hourly distribution of events shown in Figure 3(a), coincides with the area marked with an ellipse in Figure 1.

\subsection{Waveform Analysis}

Events recorded at UDG and KAD seismic stations, located very close to the quarry area are considered to be crucial in discriminating quarry blasts from earthquakes. Waveforms of earthquakes recorded at these two seismic stations from the nearby Warna seismic cluster are shown in Figure 5. The onsets of shear waves as well as surface waves are clear on these seismograms unlike in the waveforms of those from the south-east zone (Figure 6).

First motion polarities were examined for events in both the Warna cluster and the south-east zone. It can be seen that events in the latter recorded at stations over a wide azimuthal range of about 300 degrees (Figure 1) consistently show a uniformly positive polarity characteristic of blasts unlike those in the Warna cluster which have mixed polarities.

Amplitudes of the dominating frequencies of the seismograms are obtained through spectral analysis approach. The ground velocity spectra over a time window of $8 \mathrm{~s}$ duration of the vertical component seismograms at the 2 selected seismic stations, after applying butter worth band-pass filter (3 - $15 \mathrm{~Hz}$ ), are shown in Figure 7. Comparable magnitudes of the order of $\mathrm{M}_{\mathrm{L}} \sim 2$ are considered for spectral discrimination. Figures 7(a)-(b) show the spectra of earthquake seismograms of the Warna seismic cluster where the dominating amplitude is around $4 \mathrm{~Hz}$, which gradually disappears around $10 \mathrm{~Hz}$. On the other hand, the spectra for events of the south-east zone indicate a concentration of amplitude in a narrow band around $9 \mathrm{~Hz}$ (Figures 7(c)-(d)).

\section{Conclusion}

Detailed analysis of the seismic activity recorded during 2007-2013 in the Koyna-Warna region has helped in discriminating quarry blasts from earthquakes. The data set has been studied using different approaches i.e. 


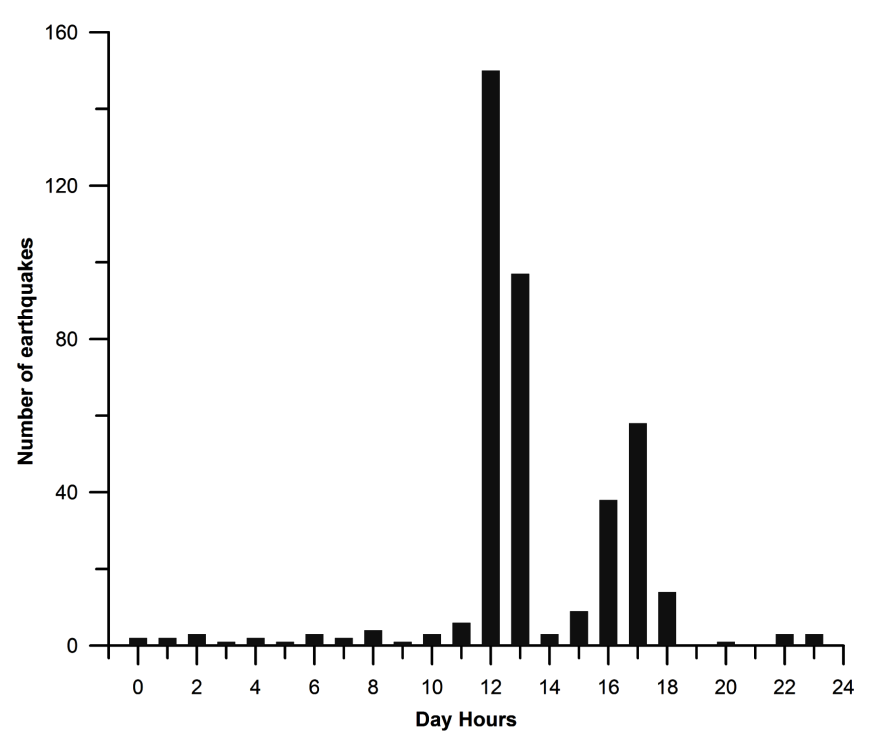

(a)

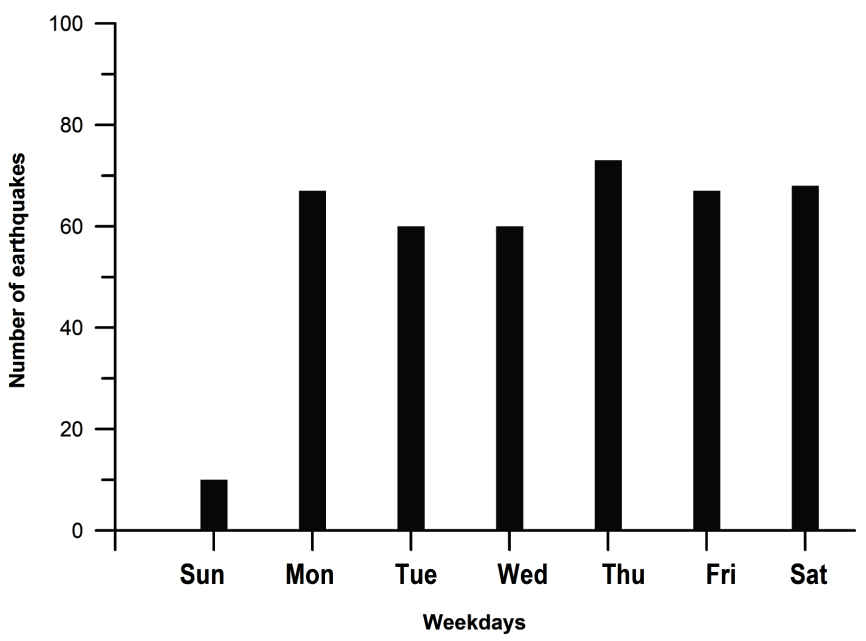

(b)

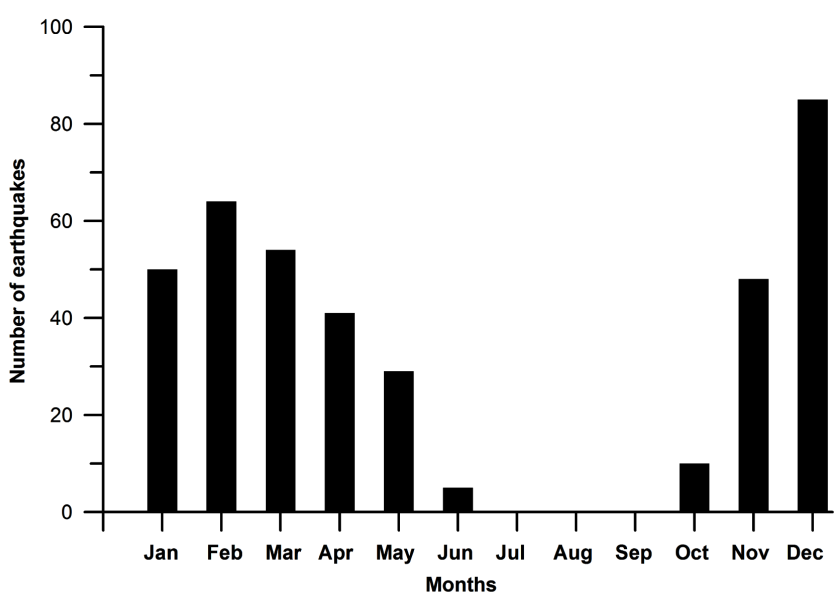

(c)

Figure 3. Distribution of number of events of the south-east zone indicated in Figure 1 with respect to (a) hour of the day (b) week days and (c) month wise during the study period. 


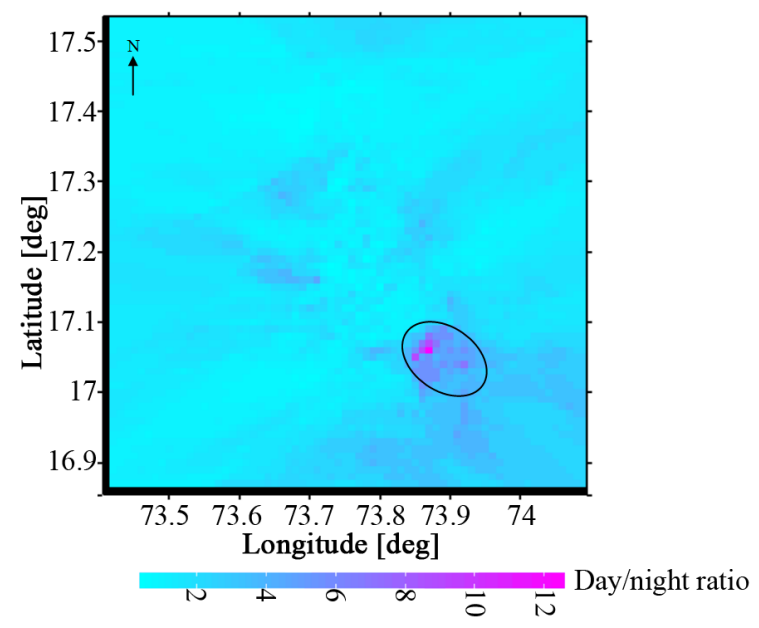

Figure 4. Variation of $R_{q}$ values for the study region by gridding the seismic activity. $R_{q}$ values greater than 1.5 , shown by an ellipse indicate the presence of quarries.

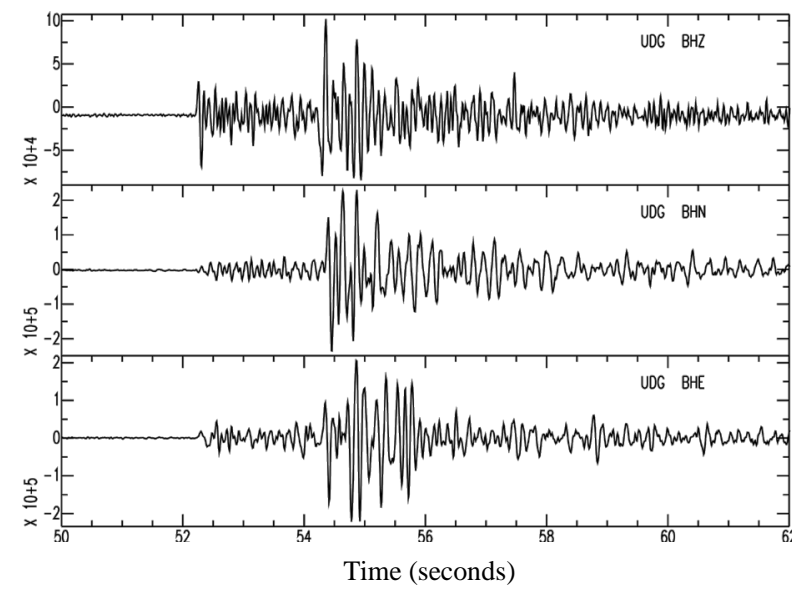

(a)

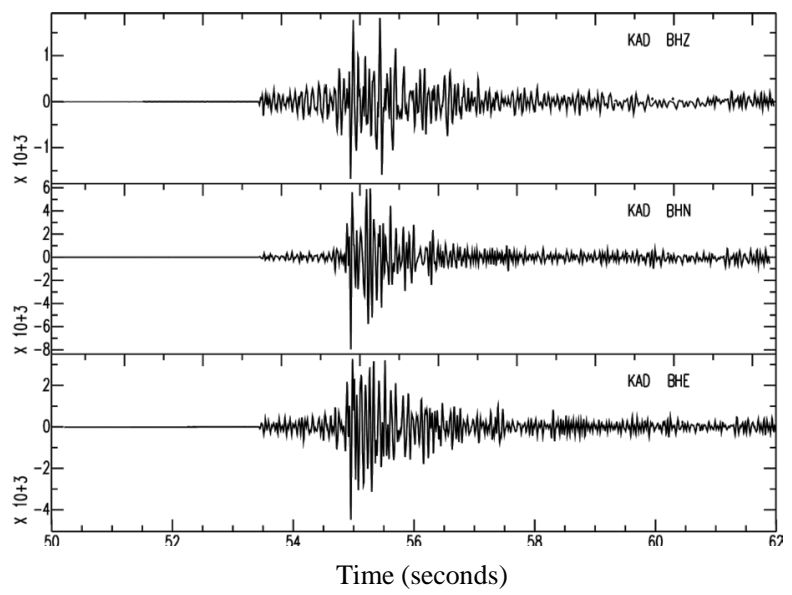

(b)

Figure 5. Observed waveforms of an earthquake of magnitude 2.0 from Warna seismic cluster recorded at seismic stations (a) UDG and (b) KAD respectively.

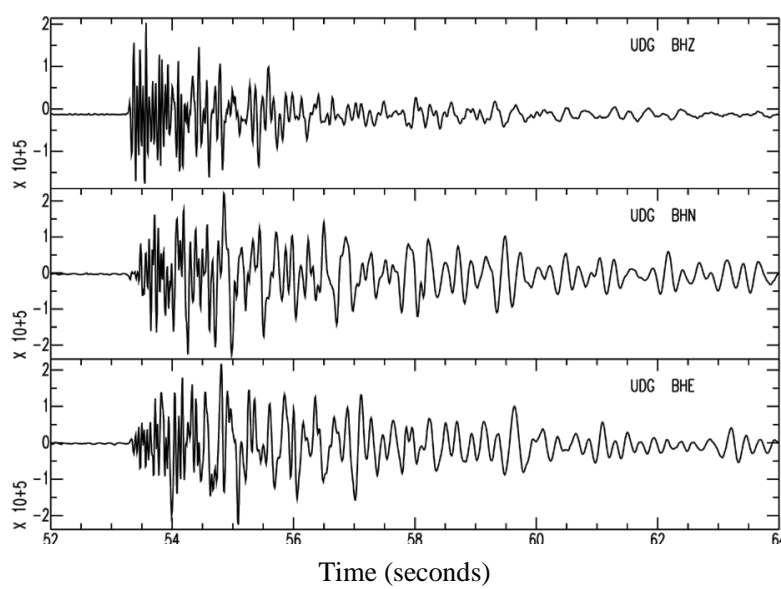

(a)

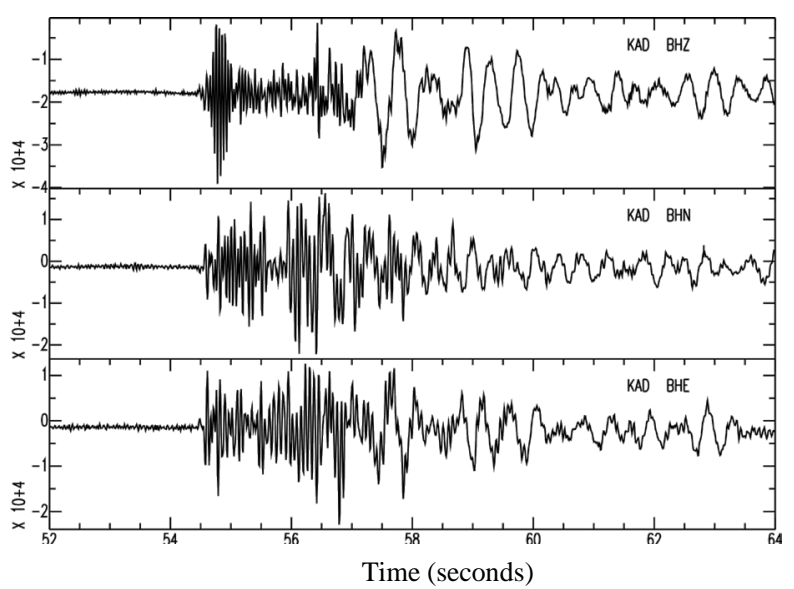

(b)

Figure 6. Observed waveforms of a blast of magnitude 2.0 of the south-east zone recorded at the nearest seismic stations (a) UDG and (b) KAD respectively. 


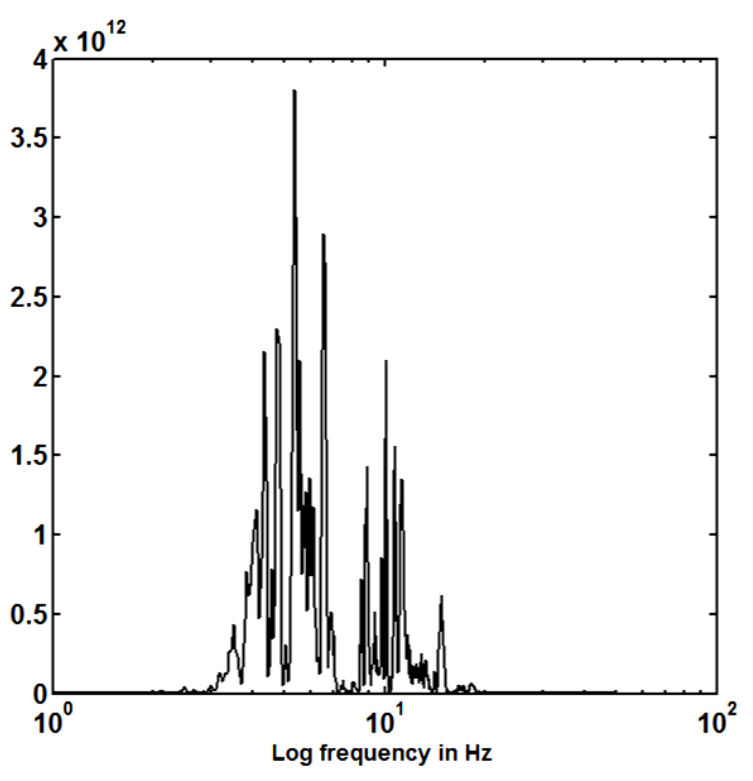

(a)

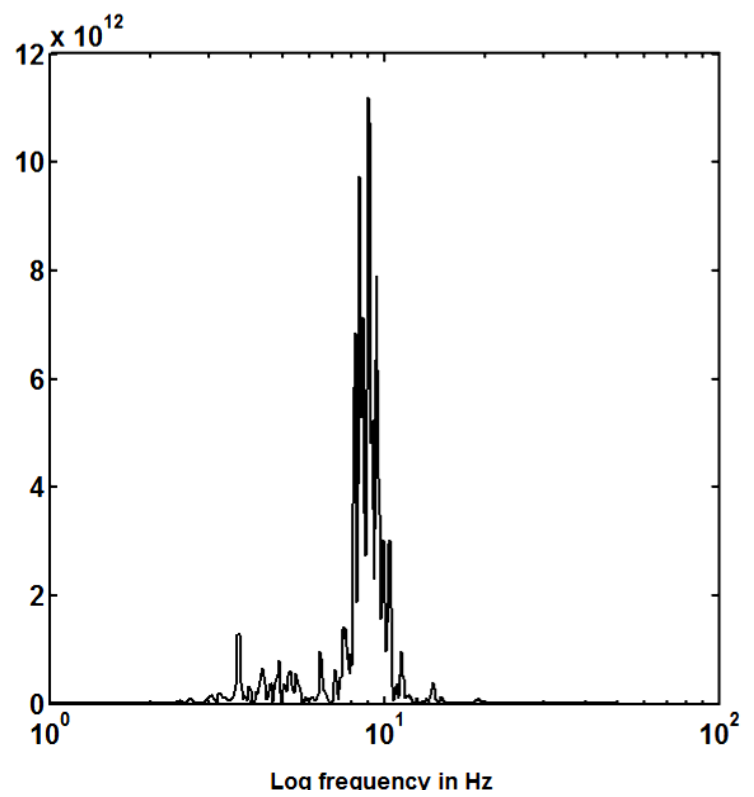

(c)

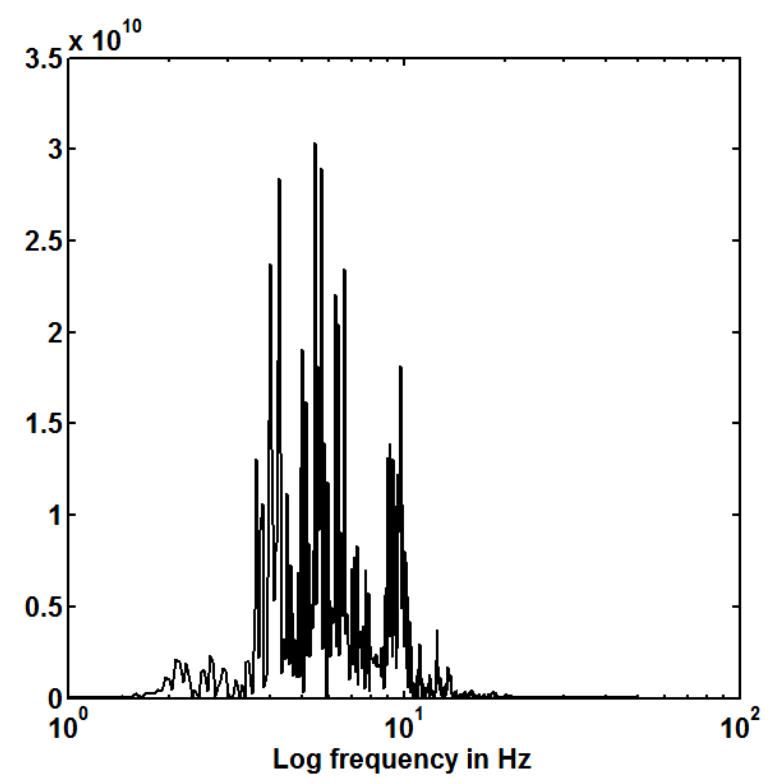

(b)

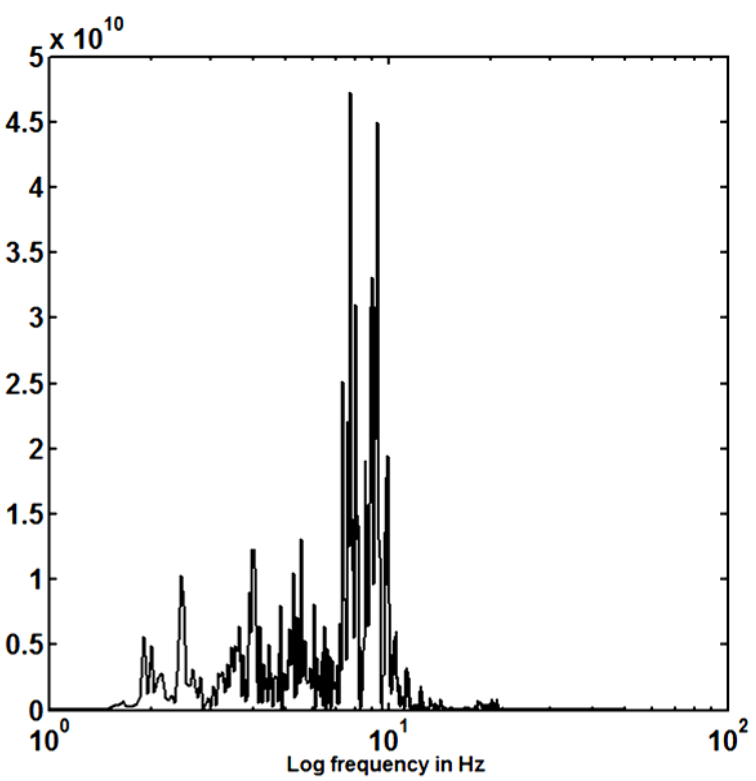

(d)

Figure 7. Amplitude spectra of an earthquake of the Warna seismic cluster recorded at seismic stations UDG and KAD (a) \& (b). Also, plotted are the amplitude spectra of a blast of the south-east zone recorded at seismic stations UDG and KAD of magnitudes 2.0 respectively (c) \& (d).

temporal observation of occurrence of events, spatial mapping of ratio of day to night time events, waveform data and spectral analysis of events. Also, a clear absence of occurrence of events is noticed during monsoon period from July to September each year when no mining activity takes place. The comprehensive analysis indicates that temporal isolation of events, high $R_{q}$ values, low energy in the surface waves, narrow frequency band around $9 \mathrm{~Hz}$ and uniform $\mathrm{P}$ wave polarities are the characteristic features that have been used for an un-ambiguous differentiation of blasts from earthquakes in the Koyna-Warna seismic zone.

\section{Acknowledgements}

The authors are thankful to the Director, CSIR-NGRI, for his constant support. The present study is carried out 
under a research program supported by the Ministry of Earth Sciences (MoES), Government of India.

\section{References}

[1] Wiemer, S. and Baer, M. (2000) Mapping and Removing Quarry Blast Events from Seismicity Catalogs. Bulletin of the Seismological Society of America, 90, 525-530. http://dx.doi.org/10.1785/0119990104

[2] Gupta, H.K. and Rastogi, B.K. (1976) Dams and Earthquakes. Elsevier Scientific Publishing Company, Amsterdam, 372.

[3] Gupta, H.K. (2002) A Review of Artificial Reservoir Triggered Earthquakes with Special Emphasis on Earthquakes in Koyna, India. Earth Science Reviews, 58, 279-310. http://dx.doi.org/10.1016/S0012-8252(02)00063-6

[4] Guha, S.K., Gosavi, P.D., Nand, K., Padale, J.G. and Marwadi, S.C. (1974) Koyna Earthquakes (October 1963 to December 1973). Report of the Central Water and Power Research Station, Poona, India.

[5] Gupta, H.K., Shashidhar, D., Metilda, P., Mandal, P., Rao, N.P., Kousalya, M., Satyanarayana, H.V.S. and Dimri, V.P. (2007) Earthquake Forecast Appears Feasible at Koyna, India. Current Science, 93, 843-848.

[6] Gupta, H.K., Shashidhar, D., Mallika, K., Rao, N.P., Srinagesh, D., Satyanarayana, H.V.S., Saha, S. and Naik, R.T.B. (2011) Short Term Earthquake Forecasts at Koyna, India. Journal of the Geological Society of India, 77, 5-11. http://dx.doi.org/10.1007/s12594-011-0001-z

[7] Rastogi, B.K. and Talwani, P. (1980) Relocation of Koyna Earthquakes. Bulletin of the Seismological Society of America, 70, 1843-1868.

[8] Rastogi, B.K., Chadha, R.K., Sarma, C.S.P., Mandal, P., Satyanarayana, H.V.S., Raju, I.P., Kumar, N., Satyamurthy, C. and Rao, A.N. (1997) Seismicity at Warna Reservoir (Near Koyna) through 1995. Bulletin of the Seismological Society of America, 87, 1484-1494.

[9] Talwani, P. (1997) On the Nature of Reservoir Induced Seismicity. Pure and Applied Geophysics, 150, 473-492. http://dx.doi.org/10.1007/s000240050089

[10] Gupta, H.K., Shashidhar, D., Pereira, M., Rao, N.P., Kousalya, M., Satyanarayana, H.V.S., Saha, S., Naik, R.T.B. and Dimri, V.P. (2007) A New Zone of Seismic Activity at Koyna, India. Journal of the Geological Society of India, 69, 1136-1137.

[11] Dahy, A. and Hassib, G.H. (2010) Spectral Discrimination between Quarry Blasts and Microearthquakes in Southern Egypt. Research Journal of Earth Sciences, 2, 1-7.

[12] Gulia, L. (2010) Detection of Quarry and Mine Blast Contamination in European Regional Catalogues. Natural Hazards, 53, 229-249. http://dx.doi.org/10.1007/s11069-009-9426-8

[13] Horasan, G., Guney, A.B., Kusmezer, A., Bekler, F., Ogutcu, Z. and Musaoglu, N. (2009) Contamination of Seismicity Catalogs by Quarry Blasts: An Example from Istanbul and Its Vicinity, Northwestern Turkey. Journal of Asian Earth Sciences, 34, 90-99. http://dx.doi.org/10.1016/j.jseaes.2008.03.012

[14] Ursino, A., Langer, H., Scarfi, L., Di Grazia, G. and Gresta, S. (2001) Discrimination of Quarry Blasts from Tectonic Microearthquakes in the Hyblean Plateau (Southeastern Sicily). Annals of Geophysics, 44, 4.

[15] Lienert, B.R.E., Berg, E. and Frazer, L.N. (1986) Hypocenter: An Earthquake Location Method Using Centered, Scaled, and Adaptively Least Squares. Bulletin of the Seismological Society of America, 76, 771-783.

[16] Lienert, B.R.E. and Havskov, J. (1995) A Computer Program for Locating Earthquakes Both Locally and Globally. Seismological Research Letters, 66, 26-36. http://dx.doi.org/10.1785/gssrl.66.5.26

[17] Wessel, P. and Smith, W.H.F. (1998) New, Improved Version of Generic Mapping Tools Released. Eos, Transactions American Geophysical Union, 79, 579. http://dx.doi.org/10.1029/98EO00426

[18] Wiemer, S. (2001) A Software Package to Analyze Seismicity ZMAP. Seismological Research Letters, 7, $373-382$. http://dx.doi.org/10.1785/gssrl.72.3.373

[19] Shashidhar, D., Rao, N.P. and Gupta, H.K. (2011) Waveform Inversion of Broad-Band Data of Local Earthquakes in the Koyna-Warna Region, Western India. Geophysical Journal International, 185, 292-304. http://dx.doi.org/10.1111/j.1365-246X.2011.04935.x

[20] Sarma, P.R. and Srinagesh, D. (2007) Improved Earthquake Locations in the Koyna-Warna Seismic Zone. Natural Hazards, 40, 563-571. http://dx.doi.org/10.1007/s11069-006-9020-2 
Scientific Research Publishing (SCIRP) is one of the largest Open Access journal publishers. It is currently publishing more than 200 open access, online, peer-reviewed journals covering a wide range of academic disciplines. SCIRP serves the worldwide academic communities and contributes to the progress and application of science with its publication.

Other selected journals from SCIRP are listed as below. Submit your manuscript to us via either submit@scirp.org or Online Submission Portal.
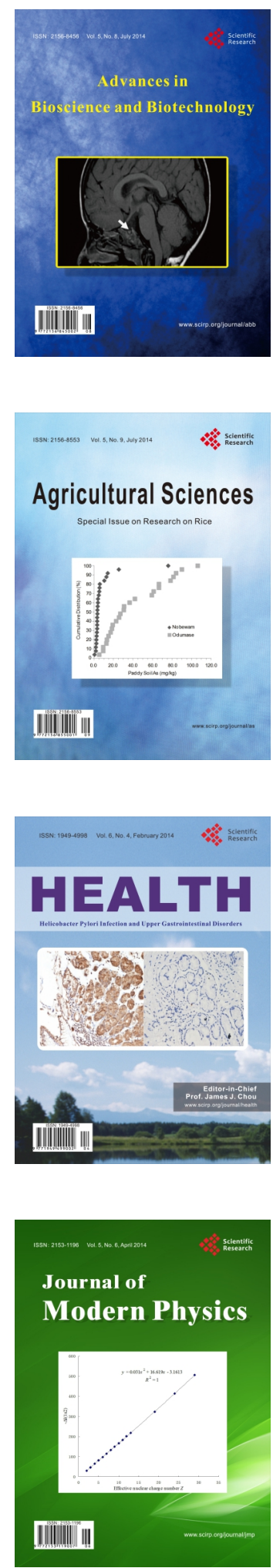
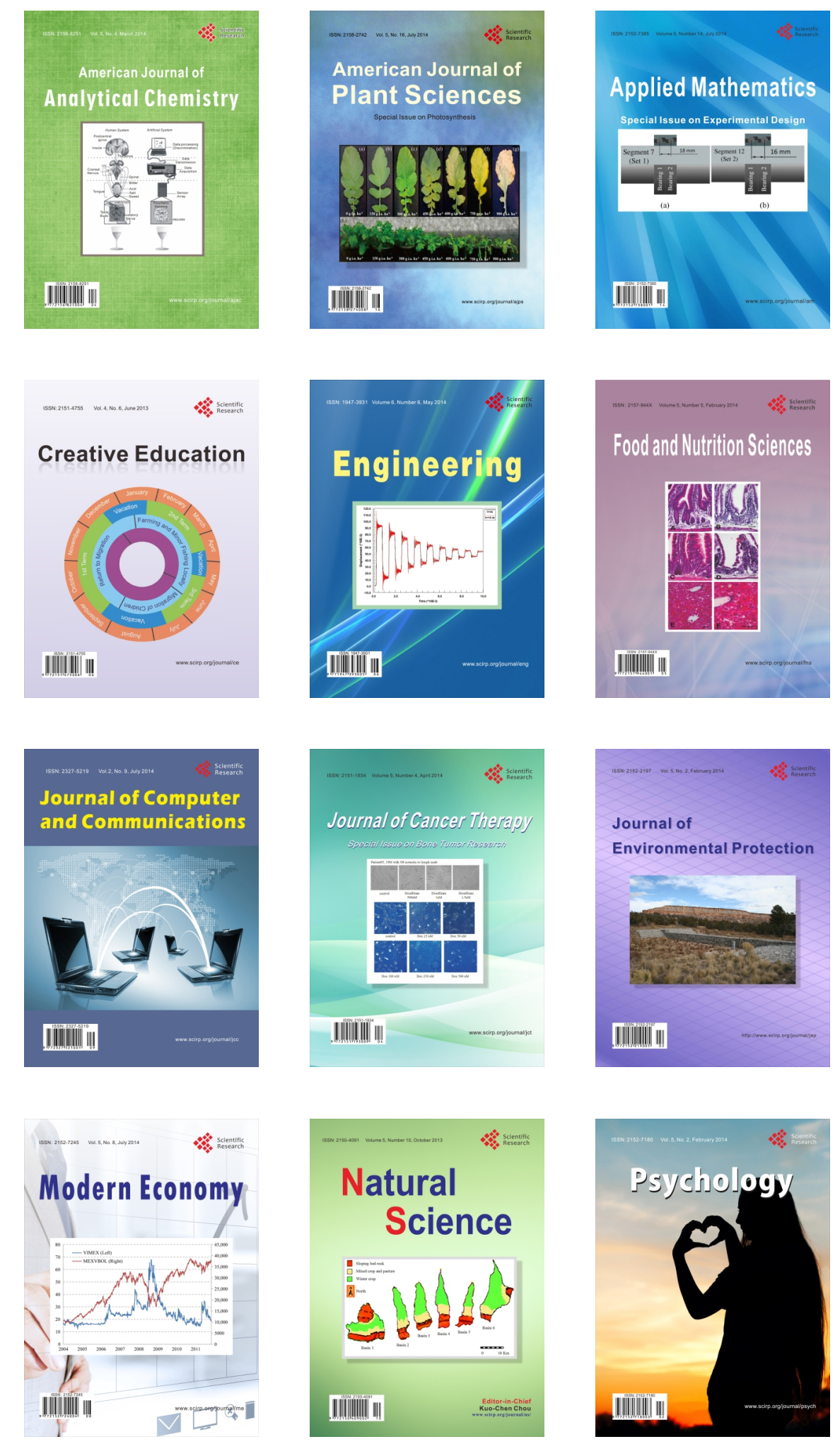